\title{
The impact of the COVID-19 pandemic on undergraduate and graduate dental courses in Brazil
}

\author{
Hélen Kaline Farias Bezerra ${ }^{\mathrm{a}, 1}$, Kamilla Karla Maurício Passos ${ }^{\mathrm{a}, 1}$, \\ Augusto César Leal da Silva Leonel ${ }^{\mathrm{a}}$, Paulo Rogério Ferreti Bonan ${ }^{\mathrm{b}}$, Hercílio Martelli-Júnior ${ }^{\mathrm{c}}$, \\ Renato Assis Machado ${ }^{\mathrm{d}}$, Flávia Maria de Moraes Ramos-Perez ${ }^{\mathrm{e}}$ and Danyel Elias da Cruz Perez ${ }^{\mathrm{e}, *}$ \\ ${ }^{a}$ School of Dentistry, Universidade Federal de Pernambuco, Recife, Pernambuco, Brazil \\ ${ }^{\mathrm{b}}$ School of Dentistry, Universidade Federal da Paraíba, João Pessoa, Paraíba, Brazil \\ ${ }^{c}$ School of Dentistry, State University of Montes Claros, Montes Claros, Minas Gerais, Brazil \\ ${ }^{d}$ Piracicaba Dental School, State University of Campinas, Piracicaba, São Paulo, Brazil \\ e School of Dentistry, Department of Clinical and Preventive Dentistry, Universidade Federal de Pernambuco, \\ Recife, Pernambuco, Brazil
}

Received 25 January 2021

Accepted 18 May 2021

\begin{abstract}
.
BACKGROUND: The COVID-19 pandemic has raised challenges in adapting to teaching and learning methods in dental education.

OBJECTIVE: This study aimed to evaluate the impact of the COVID-19 pandemic on the academic activities of undergraduate (UDG) and graduate (GD) dental students in Brazil. Additionally, students' perceptions and attitudes toward teaching activities during this period were analyzed.

METHODS: A nationwide cross-sectional survey was conducted with a sample of Brazilian UDG and GD dentistry students. Data were collected in 2020 through an online, self-administered, and anonymous questionnaire, which comprised 26 questions related to demographic data, activities of the college, family and individual student income, and attitudes and perceptions about e-learning during the pandemic. The data were tabulated and analyzed using descriptive statistics.

RESULTS: The sample included 1,166 students (779 UDG and 387 GD). Among these, 425 (54.6\%) UDG and 270 (69.8\%) GD students remotely participated in teaching activities, of which $42.6 \%$ of the UDG considered their performance in e-learning to be bad or very bad and $49.8 \%$ of the GD regarded it as good or excellent. The survey also showed that 354 (45.4\%) UDG and $102(26.4 \%)$ GD expressed a desire to discontinue the course following the outbreak of the pandemic. Among the GD, $225(58.4 \%)$ said that their experiments were completely interrupted.

CONCLUSIONS: This study reveals the poor perception and performance of dental students regarding e-learning. Additionally, the findings suggest a negative impact of the pandemic on dental education in Brazil. Effective measures should be taken to mitigate these significant consequences.
\end{abstract}

Keywords: Dental education, e-learning, online education

\footnotetext{
${ }^{1}$ These authors contributed equally for the study

*Address for correspondence: Danyel Elias da Cruz Perez Universidade Federal de Pernambuco, Departamento de Clínica e
}

Odontologia Preventiva. $4^{\text {a }}$ Travessa Professor Artur de Sá s/n. Cidade Universitária. CEP: 50740 521, Brazil. Tel.: +55 812126 8342; Fax: +55 812126 8817; E-mail: danyel.perez@ufpe.br. 


\section{Introduction}

According to recent estimates, the closure of educational institutions due to the pandemic has affected half of the students across the world — around 890 million in 114 countries [1]. Additionally, a ban on face-to-face learning implemented in several countries may disrupt the educational process [1]. Regarding dental education in Brazil, most current data show that the country has 506 dentistry colleges [2], comprising over 125,585 undergraduate students [3]. In postgraduate schools, recent data revealed that 9,300 master's and $\mathrm{PhD}$ students enrolled in 104 graduate programs [4]. Following the discontinuation of face-to-face activities, some institutions continued their operations virtually, totally, or partially, while others experienced a complete disruption of their teaching activities. This situation has proved to be challenging for universities and professors as they advance educational processes in undergraduate and graduate courses [5]. In dentistry, the key challenge is to postpone direct patient care, which is an essential component of the curriculum [6]. Virtual sessions are not capable of replicating face-to-face experiences with patients $[7,8]$. Furthermore, mandatory curricular internship activities in public services have been suspended in Brazil [8].

Brazil is regarded as an upper middle-income country, with gross domestic product per capita of US\$ 9,130 [9]. Thus, the impact of the pandemic on the economy has raised concerns. A survey showed that four out of ten Brazilians reported a loss of purchasing power since the outbreak of the pandemic [10]. With the adoption of social inclusion policies, many students from Brazilian public and private universities come from low-income families. Accordingly, owing to huge costs associated with dentistry courses, it is imperative that students take up a job to finance their education or remain financially dependent on their families. Considering the current situation due to the pandemic, it is reasonable to hypothesize that there has been an increase in dropout rates in dentistry courses in Brazil [8].

The ongoing pandemic has disrupted the lives of people across the globe, and the rapid spread of the disease has created a wave of uncertainty and anxiety regarding the future. In general, university communities suffer from high levels of stress [11]. Regarding postgraduate programs, it is estimated that the pandemic could have numerous implications for courses, tasks, seminars, and thesis defenses. The students are concerned about being at a disadvantage compared to their counterparts who have not been affected by a problem of this magnitude [12].

Although there is an absence of official data on teaching activities in dentistry during the pandemic in Brazil, it has become imperative for schools to develop e-learning plans expeditiously. However, such activities require adequate training that most Brazilian teachers lack. Moreover, the sudden commencement of online education could trigger anxiety and stress among both students and teachers [8]. The impact on income and the fear of losing a job can also generate stress.

Therefore, the aim of this study was to evaluate the consequences of the pandemic on the academic activities of undergraduate and graduate dental students in Brazil, as well as analyze students' perceptions and attitudes regarding teaching activities during this period.

\section{Methods}

The study was approved by the Research Ethics Committee (protocol 31721020.3.0000.5208) and complied with the Declaration of Helsinki. It involves a nationwide cross-sectional survey of Brazilian undergraduate and graduate dentistry students (masters and $\mathrm{PhD}$ ).

Data were collected from June 15 to July 15,2020 , during the ongoing pandemic, through an anonymous, self-administered questionnaire hosted online (Google Forms, Google ${ }^{\circledR}$ ). The sample size was calculated using Epi Info software (CDC, USA), based on data from the latest surveys on higher education in Brazil, which showed 125,585 dental undergraduate [3] and 9,300 graduate [4] students. Thus, a minimum sample of 382 undergraduates and 369 graduate students was estimated to ensure a $95 \%$ confidence level and a 5\% margin of error.

The inclusion criteria were self-declared students enrolled in undergraduate and graduate dentistry courses in Brazil, who submitted their informed consent form before participation in the study. Students were recruited through e-mail, WhatsApp®, and social media (Instagram ${ }^{\circledR}$ and Facebook ${ }^{\circledR}$ ). The questionnaire contained 26 questions related to demographic data, college activities, student income, attitudes, and perceptions about e-learning activities during the pandemic. The questions were written in Portuguese, the native language of Brazil, and were translated into English for the article presentation. The research instrument was designed to investigate 
students' perceptions of e-learning, their attitudes during this period of adaptation to the modified teaching method, and the impact of the pandemic on their families and individual income. Additionally, the impact on projects developed by graduate students was also evaluated. The answers were idealized using a five-point Likert scale, with excellent, good, regular, bad, and very bad for questions assessing students' performances in remote teaching activities. For the questions that assessed students' behavioral aspects and their preferences when comparing remote and face-to-face activities, the possible responses were strongly disagree, disagree, neither agree nor disagree, agree, and strongly agree.

Before filling the online questionnaire, all participants were informed that their identities would be completely anonymous and non-traceable, and that their participation was voluntary and could be withdrawn or renounced at any time. Moreover, a brief description of the study, as well as its objectives, risks, and benefits were available for all participants. All volunteers in the online survey submitted their informed consent forms before participation.

The responses for the variables were tabulated and analyzed using IBM SPSS Statistics software (version 20.0; IBM Corporation, Armonk, NY, USA). Descriptive analysis was performed for all variables; data are presented as percentages and numbers.

\section{Results}

Of the 1,166 students who participated in the study, $779(66.8 \%)$ were from undergraduate courses, and 387 (33.2\%) were from graduate courses. Females accounted for a major proportion of the sample $(n=919 ; 78.3 \%$ ), and the mean age was 24.8 (range, 18-60 years). Among the respondents, 454 (58.3\%) undergraduate and $102(26.5 \%)$ graduate students resided in the northeast region of the country. Additionally, 405 (52\%) undergraduate and 324 (83.7\%) graduate students belonged to a public institution. Most of them, 492 undergraduates (63.2\%) and 237 graduates $(61.6 \%)$, reported a drop in their family income due to the pandemic. Among undergraduate students, the majority $(n=697 ; 89.5 \%)$ asserted that their families were responsible for the monthly payments (private schools) and/or purchased instruments for practical activities of the course (public or private), compared to graduate students ( $n=135$; $35.1 \%)$. Among the latter, 139 (36.1\%) denied that it was the responsibility of the family, and $111(28.8 \%)$ had no cost of studies. Most of the undergraduate students $(n=627 ; 80.5 \%)$ did not work to finance their education, while most of the graduate students (214; $55.3 \%$ ) had to work to pay their college fees. Notably, $135(63 \%)$ graduates and $118(77.6 \%)$ undergraduates who worked to pay their college fees reported that their individual income decreased during the ongoing pandemic (Table 1).

Regarding teaching activities following the need for social distancing and isolation, most (425 [54.6\%] undergraduate and 270 [69.8\%] graduate students) continued with educational activities remotely (elearning) (Table 1). For those who participated in remote classes, the content taught was mostly theoretical for both undergraduates $(n=417 ; 94.1 \%)$ and graduates $(n=279 ; 97.6 \%)$. Only $26(5.9 \%)$ undergraduate students and seven $(2.5 \%)$ graduate students participated in both theoretical and practical activities remotely. Among the students who took part in remote classes, when asked how they considered their performances in relation to e-learning activities, 198 (42.6\%) undergraduates categorized it as bad or very bad, and $172(37.0 \%)$ evaluated it as regular. Conversely, 158 (49.8\%) graduate students stated that their e-learning performance was good or excellent. Additionally, 279 (60\%) undergraduate students who participated in remote classes stated that their performance was worse or much worse than that of face-to-face activities. Among graduates, 146 $(46.8 \%)$ said they were neither better nor worse, and $133(42.6 \%)$ added that they had performed worse or much worse. With regard to preference, 427 (86.8\%) undergraduate and $210(63.4 \%)$ graduate students strongly disagreed or disagreed that they preferred remote over face-to-face activities (Table 2).

Taking into account the intention to interrupt the course following the outbreak of the pandemic, $425(54.6 \%)$ undergraduate students stated that they did not intend to do so, although many $(n=354$; $45.4 \%$ ) considered this a possibility. Meanwhile, most graduate students $(n=285 ; 73.6 \%)$ did not consider discontinuing the course. In fact, a few students blocked or canceled their enrolment in the course following the pandemic. The reason for blocking enrolment can be attributed to the lack of sufficient funds to cover the payments (Table 3 ).

During the pandemic, most undergraduate and graduate students $(n=1,042 ; 89.4 \%)$ participated in online courses/events related to dentistry. Additionally, they had access to entertainment in the form of movies, television series, and similar media platforms $(n=872 ; 74.8 \%)$, with most of them $(n=980$; 
Table 1

Sociodemographic characteristics of dental students and economic impact caused by the Covid-19 pandemic

\begin{tabular}{|c|c|c|}
\hline Variables & $\begin{array}{c}\text { Undergraduate } \\
\text { students } \\
n(\%)\end{array}$ & $\begin{array}{c}\text { Graduate } \\
\text { students } \\
n(\%)\end{array}$ \\
\hline Gender & $n=779$ & $n=387$ \\
\hline Female & $616(79)$ & 29776.8 \\
\hline Male & $163(21)$ & 9023.2 \\
\hline Region of the country where the student lives & $n=779$ & $n=385$ \\
\hline North & $85(6.5)$ & $09(2.3)$ \\
\hline Northeast & $454(58.3)$ & $102(26.5)$ \\
\hline Midwest & $89(11.4)$ & $13(3.3)$ \\
\hline Southeast & $155(19.9)$ & $172(44.6)$ \\
\hline South & $30(3.9)$ & $90(23.3)$ \\
\hline The institution you study is: & $n=779$ & $n=387$ \\
\hline Public & $405(52)$ & $324(83.7)$ \\
\hline Private & $374(48)$ & $63(16.3)$ \\
\hline Has your family income been reduced because of the COVID-19 pandemic? & $n=779$ & $n=385$ \\
\hline Yes & $492(63.2)$ & $237(61.6)$ \\
\hline No & $287(36.8)$ & $148(38.4)$ \\
\hline $\begin{array}{l}\text { Considering tuition fees (private schools) and / or purchase of instruments (public and private) for clinical } \\
\text { and laboratory activities, are your family responsible for the cost of your college? }\end{array}$ & $n=779$ & $n=385$ \\
\hline Yes & $697(89.5)$ & $135(35.1)$ \\
\hline No & $64(8.2)$ & $139(36.1)$ \\
\hline I have no costs related to my course & $18(2.3)$ & $111(28.8)$ \\
\hline $\begin{array}{l}\text { If you work to pay for your studies yourself, has your individual income been reduced because of the } \\
\text { COVID-19 pandemic? }\end{array}$ & $n=779$ & $n=387$ \\
\hline Yes & $118(15.1)$ & $135(34.9)$ \\
\hline No & $34(4.4)$ & $79(20.4)$ \\
\hline I do not work to pay for my studies & $627(80.5)$ & $173(44.7)$ \\
\hline After the beginning of the COVID-19 pandemic and the need for social distance, your college: & $n=779$ & $n=387$ \\
\hline Continued with remote educational activities (e-learning) & $425(54.6)$ & $270(69.8)$ \\
\hline Activities were totally suspended & $354(45.4)$ & $117(30.2)$ \\
\hline
\end{tabular}

$84.0 \%$ ) agreeing or strongly agreeing that they spent more time on their cell phones than they did previously. The majority $(n=675 ; 57.9 \%)$ read books with content not related to dentistry. However, 299 $(38.4 \%)$ undergraduate and $195(50.4 \%)$ graduate students stated that they had studied the content of the college/graduate school to prepare themselves when face-to-face activities resume (Table 3 ).

Among the effects of the pandemic on postgraduate schools, most students $(n=225 ; 58.4 \%)$ reported that their experiments were completely interrupted and $96(24.9 \%)$ indicated partial disruption. Regarding the research project, 163 (42.3\%) students reported that they may not need adjustments, while $150(39 \%)$ said that the project should be modified, and 72 students $(18.7 \%)$ stated that another study design should be developed. The results also showed that most graduate students $(n=219 ; 56.9 \%)$ reported a delay in thesis defense due to the pandemic, while $166(43.1 \%)$ did not experience schedule changes (Table 4).

In Brazil, based on academic achievements, postgraduate courses are classified as excellent (Concept
7 or 6), very good (Concept 5), good (concept 4), or regular (Concept 3). Courses with Concepts 1 and 2 were disqualified. An overview of graduate students who participated in this survey shows that most of them $(n=140 ; 38.6 \%)$ were from graduate programs classified as good; 127 (35\%) from very good; 87 (23.9\%) from excellent; and 9 (2.5\%) from regular. Of these graduate students, most were scholarship holders financed by the Federal $(n=207 ; 53.8 \%)$ or State $(n=40 ; 10.4 \%)$ research agencies. However, 138 graduate students $(35.8 \%)$ had no scholarships.

\section{Discussion}

Many studies have been conducted on the teaching and practice of dentistry during the ongoing pandemic, addressing future perspectives of care, biosafety, and infection control in clinical teaching environments. To the best of our knowledge, this is the first study to assess the direct impact of the pandemic on the lives, projects, academic schedules, attitudes, and perceptions of dental students. 
Table 2

Students' perception of remote teaching (e-learning)

\begin{tabular}{|c|c|c|}
\hline Variables & $\begin{array}{c}\text { Undergraduate } \\
\text { students } \\
n(\%)\end{array}$ & $\begin{array}{c}\text { Graduate } \\
\text { students } \\
n(\%)\end{array}$ \\
\hline If your college continued its teaching activities remotely (e-learning), what content was taught? & $n=779 / 443$ & $n=387 / 286$ \\
\hline Theoretical classes only & $417(53.5 / 94.1)$ & $279(72.0 / 97.6)$ \\
\hline Theoretical and practical classes & $26(3.4 / 5.9)$ & $7(2.0 / 2.4)$ \\
\hline Activities at my college were totally suspended & $336(43.1)$ & $101(26.0)$ \\
\hline How did you consider your performance in e-learning activities? & $n=779 / 465$ & $n=387 / 317$ \\
\hline Excellent & $13(1.7 / 2.8)$ & $21(5.4 / 6.6)$ \\
\hline Good & $82(10.6 / 17.6)$ & $137(35.4 / 43.2)$ \\
\hline Regular & $172(22.0 / 37.0)$ & $114(29.5 / 36.0)$ \\
\hline Bad & $111(14.2 / 23.9)$ & $24(6.2 / 7.6)$ \\
\hline Very bad & $87(11.2 / 18.7)$ & $21(5.4 / 6.6)$ \\
\hline Activities at my college were totally suspended & $314(40.3)$ & $70(18.1)$ \\
\hline Compared to face-to-face activities, my performance with remote activities (e-learning) was: & $n=779 / 465$ & $n=387 / 312$ \\
\hline Much Better & $10(1.3 / 2.1)$ & $8(2.1 / 2.6)$ \\
\hline Better & $37(4.7 / 7.9)$ & $25(6.4 / 8.0)$ \\
\hline Neither better nor worse & $139(17.9 / 29.9)$ & $146(37.7 / 46.8)$ \\
\hline Worse & $160(20.5 / 34.4)$ & $105(27.1 / 33.6)$ \\
\hline Much worse & $119(15.3 / 25.6)$ & $28(7.3 / 9.0)$ \\
\hline Activities at my college were totally suspended & $314(40.3)$ & $75(19.4)$ \\
\hline I prefer remote teaching activities over face-to-face activities. & $n=779 / 492$ & $n=387 / 331$ \\
\hline Strongly disagree & $335(43 / 68.1)$ & $89(23 / 26.9)$ \\
\hline Disagree & $92(11.8 / 18.7)$ & $121(31.3 / 36.5)$ \\
\hline Neither agree nor disagree & $35(4.5 / 7.1)$ & $78(20.1 / 23.6)$ \\
\hline Agree & $16(2 / 3.2)$ & $36(9.3 / 10.9)$ \\
\hline Strongly agree & $14(1.8 / 2.8)$ & $7(1.8 / 2.1)$ \\
\hline Activities at my college were totally suspended & $287(36.9)$ & $56(14.5)$ \\
\hline
\end{tabular}

Considering social inequities and the poor availability of resources to deal with this situation, many Brazilian universities have suspended their face-toface activities, with some institutions continuing to teach in virtual learning environments (e-learning). However, others are assessing the best ways to resume classes, taking into consideration this entire context. In Brazil, only one local-based study evaluated the quality of life of dental undergraduate students at the beginning of social isolation due to the pandemic [13].

Dentistry is among the professions that face a high risk of COVID-19 transmission, both for specialists and patients. This factor makes it even more difficult to return to face-to-face classes, especially in clinical teaching activities. Thus, distance learning has spread extensively. However, distance activity cannot replace the experience of direct contact with a patient $[6,7]$. In dentistry courses in Brazil, in addition to clinical academic activities, curricular internships have also been suspended, affecting several students' academic schedules [8]. Most of the participants in this study stated that their educational institution continued with distance learning activities, with most of the curriculum covering only theoretical classes.
Meanwhile, $45.4 \%$ of undergraduate and $30.2 \%$ of graduate students faced a total suspension of teaching activities. In this scenario, students who are experiencing changes to the teaching method are concerned about facing learning disadvantages compared with students who have not experienced a crisis like this [12]. For this reason, many students are insecure in managing patients post pandemic because of the absence of practical training with direct contact with patients [14]. Moreover, the pandemic may have had a major impact on the future of students, especially regarding the challenges of completing academic activities and taking the final exam [15].

Although distance learning is already well established in some educational institutions and studies have highlighted its effectiveness in the learning process $[16,17]$, most students may not be receptive to this method. In this study, the majority of students stated that they preferred face-to-face activities compared to e-learning. Regarding academic achievement, among students who are participating in online classes, most undergraduate students considered their performance to be bad or very bad. In contrast, most graduate students regarded their performance as excellent or good. When compared to 
Table 3

Students' perceptions about the course and attitudes during the COVID-19 pandemic

\begin{tabular}{|c|c|c|}
\hline Variables & $\begin{array}{c}\text { Undergraduate } \\
\text { students } \\
n(\%)\end{array}$ & $\begin{array}{c}\text { Graduate } \\
\text { students } \\
n(\%)\end{array}$ \\
\hline After the start of the pandemic, did you feel like stopping the course? & $n=779$ & $n=387$ \\
\hline Yes & $354(45.4)$ & $102(26.4)$ \\
\hline No & $425(54.6)$ & $285(73.6)$ \\
\hline Did you, in fact, cancel your course enrollment after the pandemic began? & $n=779$ & $n=387$ \\
\hline Yes & $4(0.5)$ & $2(0.5)$ \\
\hline No & $775(99.5)$ & $385(99.5)$ \\
\hline During the pandemic I participated in online courses/events related to dentistry. & $n=779$ & $n=387$ \\
\hline Yes & $676(86.8)$ & $366(94.6)$ \\
\hline No & $103(13.2)$ & $21(5.4)$ \\
\hline During the pandemic I consumed a lot of entertainment on movie platforms, series, and the like. & $n=779$ & $n=387$ \\
\hline Strongly disagree & $35(4.5)$ & $17(4.4)$ \\
\hline Disagree & $54(6.9)$ & $60(15.5)$ \\
\hline Neither agree nor disagree & $85(11.0)$ & $43(11.1)$ \\
\hline Agree & $276(35.4)$ & $133(34.4)$ \\
\hline Strongly agree & $329(42.2)$ & $134(34.6)$ \\
\hline During the pandemic I read books of general content, not related to dentistry. & $n=779$ & $n=387$ \\
\hline Yes & $451(57.9)$ & $224(57.9)$ \\
\hline No & $328(42.1)$ & $163(42.1)$ \\
\hline During the pandemic I studied dentistry contents to be more prepared when activities return. & $n=779$ & $n=387$ \\
\hline Strongly disagree & $86(11.0)$ & $18(4.7)$ \\
\hline Disagree & $124(16.0)$ & $36(9.3)$ \\
\hline Neither agree nor disagree & $161(20.6)$ & $76(19.6)$ \\
\hline Agree & $299(38.4)$ & $195(50.4)$ \\
\hline Strongly agree & $109(14.0)$ & $62(16.0)$ \\
\hline During the pandemic I spent more time on my cell phone than usual (pre-pandemic period). & $n=779$ & $n=387$ \\
\hline Strongly disagree & $14(1.8)$ & $4(1.0)$ \\
\hline Disagree & $45(5.8)$ & $30(7.7)$ \\
\hline Neither agree nor disagree & $63(8.1)$ & $30(7.7)$ \\
\hline Agree & $258(33.1)$ & $149(38.6)$ \\
\hline Strongly agree & $399(51.2)$ & $174(45.0)$ \\
\hline
\end{tabular}

face-to-face activities, most students indicated that the e-learning experience was worse or much worse. Some information may help elucidate these worrying findings. Due to social distancing and isolation accompanying the pandemic, many Brazilian dental schools have immediately migrated their teaching to e-learning platforms [8]. In Brazil, most dental professors are untrained to implement remote education. Given this reality, higher education institutions must provide protocols and training for teachers to deal with online teaching challenges and students' learning difficulties in this changed environment [18]. We must also consider the unfavorable context of the crisis triggered by the pandemic, which results in fear and anxiety [19]. This could contribute to students' negative perceptions of e-learning. Additionally, the affective component represented by the presence of the teacher and colleagues may be an important learning factor during face-to-face activities [20, 21]. Future studies are essential to better comprehend these data. Nevertheless, dental schools must consider these issues to develop effective strategies for improving the experience and perception of students toward e-learning. The poor perception of remote education associated with low academic achievement could be discouraging and negatively impact student training. This environment may also contribute to increasing dropout rates.

An earlier survey revealed that many Brazilians experienced loss in family income, either due to a reduction in wages or unemployment, because of the pandemic [10], which was confirmed by our findings. This is particularly concerning for dental education in Brazil. Dentistry is an expensive program, and most Brazilian undergraduate students depend on their families to meet their expenses. Moreover, many undergraduate and graduate students who worked to pay for their education reported a reduction in their income. These data reveal that the risk of increased dropout in dentistry courses in Brazil is veritable, particularly among undergraduates. Thus, administrations of higher education institutions, both public and private, should be cognizant of the situation to carefully monitor the students and consider strategies 
Table 4

Impact of COVID-19 pandemic on the graduate students' projects

\begin{tabular}{|c|c|}
\hline Variables & $\begin{array}{c}\text { Graduate } \\
\text { students } \\
n(\%)\end{array}$ \\
\hline $\begin{array}{l}\text { Owing the COVID-19 pandemic, your experiments } \\
\text { were }\end{array}$ & $n=385$ \\
\hline Totally interrupted & $225(58.4)$ \\
\hline Partially interrupted & $96(24.9)$ \\
\hline There was no impairment to the experiments & $64(16.6)$ \\
\hline $\begin{array}{l}\text { Owing the COVID-19 pandemic, your research } \\
\text { project }\end{array}$ & $n=385$ \\
\hline It will not need adjustments & $163(42.3)$ \\
\hline It must be adjusted & $150(39.0)$ \\
\hline I will have to design another project & $72(18.7)$ \\
\hline $\begin{array}{l}\text { Owing the COVID-19 pandemic, the date of thesis } \\
\text { defense }\end{array}$ & $n=385$ \\
\hline There will be delay & $219(56.9)$ \\
\hline The schedule will not be changed & $166(43.1)$ \\
\hline
\end{tabular}

for minimizing the negative consequences of the pandemic. Furthermore, additional credit lines can be used from public funding.

Students have been greatly affected by the pandemic, and most of them are in an age group that is extremely susceptible to disturbances in sleep, mood, anxiety, and depression [22-24]. This may explain why many undergraduate and graduate students expressed an intention to interrupt the course since the beginning of the pandemic. However, in effect, only a few suspended it. In addition to their studies, students who hold multiple roles tend to have higher levels of personal stress and pressure [25]. Considering the ongoing pandemic, it is important to highlight that educational institutions should anticipate a possible increase in school dropout rates. Regarding the learning behaviors of these students during the pandemic, it is imperative to emphasize the significance of continuing online education for acquiring skills and knowledge, maintaining performance, and ensuring good care of patients [26, 27]. Most subjects in this study stated that they participated in online meetings and lectures related to dentistry. Moreover, many indicated that they are also studying university content to be more prepared when face-to-face activities resume.

In our study, the students stated that they spent more time on their cell phones during the pandemic than they did previously. Additionally, it was also possible to verify that they had sufficient access to entertainment through films, series on television, and other media platforms. Linjawi et al. [28] found that, although students reported acceptable levels of skills with digital resources, they preferred to use such tools for personal use rather than for educational purposes. This scenario is extremely complex. In this context, the excessive use of cell phones for personal purposes can be an additional distracting factor, explaining, at least in part, the students' poor cognizance regarding e-learning. This resulted in their perception of worse academic performance when compared to face-toface teaching.

Brazil excels in global dental research and is the second country in the world in terms of the number of articles published [29]. Additionally, there is an assembly of high-impact studies in all areas of dentistry. The impact of the pandemic on graduate students and consequently in postgraduate courses can negatively influence Brazilian dental research, since postgraduate courses are responsible for almost all scientific research in the country. Most graduate students affirmed that their experiments were completely or partially interrupted because of the pandemic. Because of the pandemic, most respondents reported that they would be required to adjust or develop another study design, resulting in a delay in thesis defense.

Although this is the first major study to evaluate the impact of the pandemic on dental education, some limitations should be considered. All data collected are self-reported, which are subject to two types of bias-recall and social desirability bias-that is, the tendency to underreport socially undesirable attitudes and behaviors. In this study, a recall bias may explain the minor disagreement between the number of students who reported the complete suspension of their teaching activities and those who commented on their experiences regarding remote education during the pandemic. Some students may have considered previous experiences with e-learning before the pandemic or even based their responses on how they would feel if they had experienced e-learning. Such disagreements were minimal and did not influence the relevance of the data. Additionally, the web-based convenience sample may result in selection bias, with a given population being over- or under-represented. However, because of the COVID-19 pandemic, all Brazilian dental schools were closed during data collection. Thus, considering the current situation, this was the only viable method for such surveys. Online recruitment has become an important strategy in the pandemic scenario because sanitary measures prevent traditional research approaches, and people have been spending more time on social media. Moreover, online recruitment is effective and provides a large sample in a short time [30]. 


\section{Conclusion}

This study highlights the most impactful academic consequences of dental undergraduate and graduate teaching. There was a poor perception and performance of dental students regarding e-learning. The findings suggest a significant impact of the pandemic on dental education. The extent of this impact can only be measured in the future. How are universities, including dental schools, planning to deal with schedule delays, financial difficulties, and the possible negative emotions of students? This study provides important information about the current scenario of dental education in Brazil in the context of the COVID-19 pandemic and its impact on the lives of both undergraduate and graduate students. The data may aid university managers and professors on the urgent measures required to mitigate the impact on dental education, particularly in low- and mediumincome countries.

\section{Acknowledgments}

The study was supported by the Coordenação de Aperfeiçoamento de Pessoal de Nível Superior (CAPES), Brazil (finance code 001), and Conselho Nacional de Desenvolvimento Científico e Tecnológico (CNPq), Brazil.

\section{Conflict of interest}

The authors declare no conflict of interest.

\section{Data availability statement}

The data that support the findings of this study are available from the corresponding author upon reasonable request.

\section{References}

[1] United Nations Educational, Scientific and Cultural Organization. COVID-19 educational disruption and response. 2020 [updated 2021 Apr 28; cited 2020 Nov 11]. Available from: https://en.unesco.org/covid19/educationresponse.

[2] Ministério da Educação. Cadastro Nacional de Cursos e Instituições de Educação Superior (Cadastro e-MEC). 2020 [updated 2021 Apr 28; cited 2020 Nov 11]. Available from: https://emec.mec.gov.br.
[3] INEP. Sinopses Estatísticas da Educação Superior Graduação. 2020 [updated 2021 Apr 28; cited 2020 Nov 11]. Available from: http://portal.inep.gov.br/web/guest/ sinopses-estatisticas-da-educacao-superior.

[4] Coordenação de Aperfeiçoamento de Pessoal de Nível Superior (CAPES) - Ministério da Educação. 2020 [updated 2021 Apr 28; cited 2020 Nov 11]. Available from: https:// sucupira.capes.gov.br/sucupira/public/consultas/coleta/ programa/quantitativos/quantitativoles.jsf?areaAvaliacao= $18 \&$ areaConhecimento $=40200000$.

[5] Newman NA, Lattouf OM. Coalition for medical education-A call to action: A proposition to adapt clinical medical education to meet the needs of students and other healthcare learners during COVID-19. J Card Surg. 2020; 35(6):1174-5.

[6] American Dental Association. Accreditation standards for dental education programs. 2020 [updated 2020 July; cited 2020 Nov 11]. https://www.ada.org//media/CODA/Files/ Predoc_Standards_July2020.pdf.

[7] Iyer P, Aziz K, Ojeius D. Impact of COVID-19 on dental education in the United States. J Dent Educ. 2020;84(6): 718-22.

[8] Machado RA, Bonan PRF, Perez DEDC, Martelli-Júnior H. COVID-19 pandemic and the impact on dental education: discussing current and future perspective. Braz Oral Res. 2020;34:e083.

[9] The World Bank. GNI per capita, Atlas method (current US\$). 2020 [updated 2021 Apr 28; cited 2020 Nov 11]. Available from: https://data.worldbank.org/indicator/NY. GNP.PCAP.CD?year_high_desc=true.

[10] Agência Brasil. COVID-19:40\% of Brazilians faced total or partial income loss, 2020. https://agenciabrasil.ebc.com. br/en/economia/noticia/2020-05/covid-19-40-braziliansfaced-total-or-partial-income-loss. Accessed November 11, 2020.

[11] Al-Rabiaah A, Temsah MH, Al-Eyadhy AA, Hasan GM, Al-Zamil F, Al-Subaie S, et al. Middle East Respiratory Syndrome Corona Virus (MERS-CoV) associated stress among medical students at a university teaching hospital in Saudi Arabia. J Infect Public Health. 2020;13(5):687-91.

[12] Daniel SJ. Education and the COVID-19 pandemic. Prospects. 2020;49:91-96.

[13] Silva PGB, de Oliveira CAL, Borges MMF, Moreira DM, Alencar PNB, Avelar RL, et al. Distance learning during social seclusion by COVID-19: improving the quality of life of undergraduate dentistry students. Eur J Dent Educ. 2021;25(1):124-34.

[14] Abbasi MS, Ahmed N, Sajjad B, Alshahrani A, Saeed S, Sarfaraz $\mathrm{S}$, et al. E-Learning perception and satisfaction among health sciences students amid the COVID-19 pandemic. Work. 2020;67:549-56.

[15] Sahu P. Closure of universities due to coronavirus disease 2019 (COVID-19): Impact on education and mental health of students and academic staff. Cureus. 2020;12(4):e7541.

[16] George PP, Papachristou N, Belisario JM, Wang W, Wark PA, Cotic Z, et al. Online eLearning for undergraduates in health professions: A systematic review of the impact on knowledge, skills, attitudes and satisfaction. J Glob Health. 2014;4(1):010406.

[17] Liu Q, Peng W, Zhang F, Hu R, Li Y, Yan W. The effectiveness of blended learning in health professions: Systematic Review and Meta-Analysis. J Med Internet Res. 2016;18(1):e2.

[18] Sarfaraz S, Ahmed N, Abbasi MS, Sajjad B, Vohra F, AlHamdan RS, et al. Self-perceived competency of the medical 
faculty for E-Teaching during the COVID-19 pandemic. Work. 2020;67:791-8.

[19] Fofana NK, Latif F, Sarfraz S, Bilal, Bashir MF, Komal B. Fear and agony of the pandemic leading to stress and mental illness: An emerging crisis in the novel coronavirus (COVID-19) outbreak. Psychiatry Res. 2020;291:113230.

[20] Jowsey T, Foster G, Cooper-Ioelu P, Jacobs S. Blended learning via distance in pre-registration nursing education: A scoping review. Nurse Educ Pract. 2020;44:102775.

[21] Naddeo A, Califano R, Fiorillo I. Identifying factors that influenced wellbeing and learning effectiveness during the sudden transition into eLearning due to the COVID-19 lockdown. Work. 2021;68:45-67.

[22] Wang C, Pan R, Wan X, Tan Y, Xu L, McIntyre RS, et al. A longitudinal study on the mental health of general population during the COVID-19 epidemic in China. Brain Behav Immun. 2020;87:40-8.

[23] Null GL, Pennesi, L, Feldman M. Nutrition and lifestyle intervention on mood and neurological disorders. J Evid Based Complementary Altern Med. 2017;22(1):68-74.

[24] Yuan S, Liao Z, Huang H, Jiang B, Zhang X, Wang Y, et al. Comparison of the indicators of psychological stress in the population of Hubei Province and non-endemic provinces in China during two weeks during the coronavirus disease 2019 (COVID-19) outbreak in February 2020. Med Sci Monit. 2020;26:e923767.

[25] Dacanay AP, Vaughn S, Orr M, Andre J, Mort K. Factors contributing to nursing distance education student success. J Nurs Educ Pract. 2015;5(2):34-9.

[26] da Cruz Perez DE, Passos KKM, Machado RA, MartelliJúnior H, Bonan PRF. Continuing education in oral cancer during coronavirus disease 2019 (covid-19) outbreak. Oral Oncol. 2020;105:104713.

[27] Kanneganti A, Sia CH, Ashokka B, Ooi SBS. Continuing medical education during a pandemic: an academic institution's experience. Postgrad Med J. 2020;96(1137):384-6.

[28] Linjawi AI, Alfadda LS. Students' perception, attitudes, and readiness toward online learning in dental education in Saudi Arabia: a cohort study. Adv Med Educ Pract. 2018; 9:855-63.

[29] Scimago Journal \& Country Rank. 2020 [updated 2021 Apr 28; cited 2020 Nov 11]. Available from: https://www. scimagojr.com/countryrank.php?area $=3500$.

[30] Moraes RR, Correa MB, Daneris A, Queiroz AB, Lopes JP, Lima GS, et al. Email vs. Instagram recruitment strategies for online survey research. Braz Dent J. 2021;32:67-77. 